\title{
Factors Affecting Community Empowerment During Disaster Recovery
}

Tony Van Krieken, SUniversity of Salford, Salford, UK

Chaminda Pathirage, University of Wolverhampton, Wolverhampton, UK

\begin{abstract}
The purpose of this study is to explore and identify the factors for empowering the community during the Disaster Recovery phase. It is very important to recognize the community (decision makers) as being empowered of their fate but not to inform, consult and having others to decide their fate. The study investigates the important role of the project manager who coordinates and communicates with the community members in order to empower them to achieve a long-term sustainability. The findings obtained from the literature review and the case studies allow identifying the factors for empowering the community during Disaster Recovery, such as: participation in decision-making; use of social capital within the community; thinking and doing SMART; recognizing community power; building capacity; and helping your neighbors. The results of this study provide guidelines for Project Managers to empower the community as decisions makers in the disaster recovery phase.
\end{abstract}

\section{KEYWORDS}

Community, Disaster, Empowerment, Survivors 


\section{INTRODUCTION}

According to the online Cambridge Dictionary, empowerment is "the process of gaining freedom and power to do what you want or to control what happens to you." In other words, the community is to be given the freedom and power to control what happens to themselves during disaster recovery and long-term sustainment. The community participates in the decision-making of their recovery and responsible for their actions with the major stakeholders in the disaster recovery project. Involvement in decisionmaking should take place at all phases of the project from initiation to closure.

The community is the first and often remains the sole line of response for weeks during a disaster (Brennan, 2005). Furthermore, numerous studies from Asia have stressed effective community participation in all phases of disaster management (Chandrarsekhar, 2012; Crawford, 2013; Magnin, 2007; Olofsson, 2007; Twigg, 2009; World Bank, 2005, 2008). The members within the community help each other at the local and national level to rebuild the community, as shown in disasters that occurred at New Orleans, Tacloban City and California (Anderson, 2008; Bolin, 2006). Community collaboration has been successful in Asia (Ainuddin, 2012; Bornstein, 2013; Chandrarsekhar, 2012) by government and community working closely together in different types of influence/power relationships from ad hoc to empowerment; but unsuccessful in other parts of the world, such as indicated in Davidson's work (Davidson, 2006) and in New Orleans with Hurricane Katrina (Barnshaw, 2006). Communities in New Orleans turned the situation around in which people restored their personal and community lives (Anderson, 2008; Barnshaw, 2006; Bolin, 2006) by working together to rebuild their community.

Rowlands (2013) indicates that empowering the community and maximizing the community's participation at the local level will give the community control of the process and enable it to take charge of its rebuilding. This means tapping into the community's resourcefulness; tapping local providers to supply materials and services (such as psychology and social work); and tapping workers to rebuild the community is required to ensure meaningful disaster recovery projects. Araki (2013) observed that some communities might have the ability to promote such processes by themselves, but the majority need a facilitator to assist and empower them.

This paper investigates how the community is engaged during disaster recovery and how they can be empowered in order to explore and identify key empowerment factors for their sustainment. In summary:

- Community is the First Responder within the first 72 hours.

- Community has inner strengths to regroup, restore and rebuild for the future.

- First step for family, kin, strangers and community members to work together.

- Community recognize as being empowered (decision makers) of their fate; not have others to decide their fate.

- How can the Project Manager can ensure the empowerment of the community will take place during the various disaster recovery projects, such as roads, community centers, churches, and houses? 


\section{LITERATURE REVIEW}

Davidson (2006) analyzed community participation, including empowerment, in four post-disaster housing reconstruction projects in Colombia, El Salvador, and Turkey to understand how the community participated in the projects. Some of the communities were informed, other were consulted but were not empowered; in essence they had no power to affect the deliverables of the project. The ladder of community participation envisioned by Davidson is shown in Figure 1. The steps of the ladder outline strategies for community participation. Top of the ladder is empowerment, based upon decisionmaking roles, and the next step on the ladder is collaborate which is based on when the community has control over the project. On the bottom of ladder, the community may be consulted about their needs to merely being informed what will take place in the project. The recommendation of Davidson's study was:

a) To have the community participate in the procurement process of the project: deciding the work to be completed and prioritizing the work to be completed.

b) Community participation should take place before the disaster rather than during post-disaster to make sound decisions in a non-chaotic environment.

In 1990, the International Association of Public Participation Practitioners was formed to respond to professionals interested in standards and practices of public participation as shown in Figure 2.

The professionals are individuals, governments, institutions and other bodies that affect public interest. The framework, illustrated in Figure 2, lays out the tools, techniques, methods and strategies of community participation from ad hoc to empowerment. The association provides explicit guidelines to professionals and even to those involved in Disaster Management. The association is global, but a lot of work has been completed in Australia and New Zealand within Disaster Management. According to the IAP2 Framework, the methods/strategies of community participation are:

1) Inform - Keep the community informed through Websites, Fact Sheets and Open Houses

2) Consult - Obtain community input on analysis, alternatives and/or decisions through focus groups, surveys, and public meetings

3) Involve - Community concerns and aspirations are consistently understood and considered through workshops

4) Collaborate - Seek community advice and incorporate the advice and recommendations into the solution through advisory committees

5) Empower - Place final decision-making in the hands of the community through citizen juries, ballots and delegated decisions.

IAP2 stresses empowerment as final decision-making; but Christ Church Government stressed that final decision making which is made by the Government, 

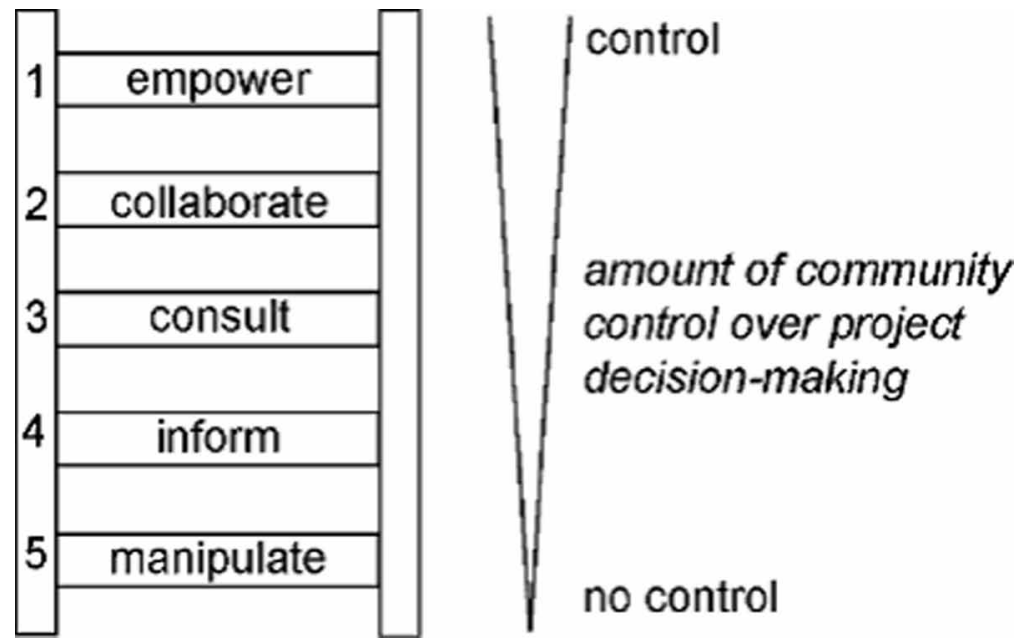

Figure 2. Spectrum of Public Participation (IAP, 2007)

\section{iap2 public participation spectrum}

developed by the international association for public participation

\begin{tabular}{|c|c|c|c|c|c|}
\hline & INFORM & CONSULT & INYOLVE & COLLABORATE & EMPOWER \\
\hline $\begin{array}{l}\text { PUBLC } \\
\text { PARIICIPATION } \\
\text { COAL }\end{array}$ & $\begin{array}{l}\text { To provide } \\
\text { the public } \\
\text { with balanced } \\
\text { and objective } \\
\text { information to } \\
\text { assist them in } \\
\text { understanding } \\
\text { the problems, } \\
\text { alternatives and/or } \\
\text { solutions. }\end{array}$ & $\begin{array}{l}\text { To obtain public } \\
\text { feedback } \\
\text { on analysis, } \\
\text { alternatives and/or } \\
\text { decision. }\end{array}$ & $\begin{array}{l}\text { To work directly } \\
\text { with the public } \\
\text { throughout the } \\
\text { process to ensure } \\
\text { that public issues } \\
\text { and concerns } \\
\text { are consistently } \\
\text { understood and } \\
\text { considered. }\end{array}$ & $\begin{array}{l}\text { To partner with } \\
\text { the public in each } \\
\text { aspect of the } \\
\text { decision including } \\
\text { the development of } \\
\text { alternatives and the } \\
\text { identification of the } \\
\text { preferred solution. }\end{array}$ & $\begin{array}{l}\text { To place final } \\
\text { decision-making } \\
\text { in the hands of } \\
\text { the public. }\end{array}$ \\
\hline $\begin{array}{l}\text { PROMISETO } \\
\text { THEPUBLIC }\end{array}$ & $\begin{array}{l}\text { We will keep you } \\
\text { informed. }\end{array}$ & $\begin{array}{l}\text { We will keep you } \\
\text { informed, listen to } \\
\text { and acknowledge } \\
\text { concerns and } \\
\text { provide feedback } \\
\text { on how public input } \\
\text { influenced the } \\
\text { decision. }\end{array}$ & $\begin{array}{l}\text { We will work with } \\
\text { you to ensure that } \\
\text { your concerns } \\
\text { and issues are } \\
\text { directly reflected } \\
\text { in the alternatives } \\
\text { developed and } \\
\text { provide feedback } \\
\text { on how public input } \\
\text { influenced the } \\
\text { decision. }\end{array}$ & $\begin{array}{l}\text { We will look to you } \\
\text { for direct advice } \\
\text { and innovation } \\
\text { in formulating } \\
\text { solutions and } \\
\text { incorporate } \\
\text { your advise and } \\
\text { recommendations } \\
\text { into the decisions to } \\
\text { the maximum extent } \\
\text { possible. }\end{array}$ & $\begin{array}{l}\text { We will implement } \\
\text { what you decide. }\end{array}$ \\
\hline EXAMPLETOOLS & $\begin{array}{l}\text { - Fact sheets } \\
\text { - Websites } \\
\text { - Open houses }\end{array}$ & $\begin{array}{l}\text { - Public comment } \\
\text { - Focus groups } \\
\text { - Surveys } \\
\text { - Public meetings }\end{array}$ & $\begin{array}{l}\text { - Workshops } \\
\text { - Deliberate polling }\end{array}$ & $\begin{array}{l}\text { - Citizen Advisory } \\
\text { committees } \\
\text { - Consensus- } \\
\text { building } \\
\text { - Participatory } \\
\text { decision-making }\end{array}$ & $\begin{array}{l}\text { - Citizen juries } \\
\text { - Ballots } \\
\text { - Delegated } \\
\text { decisions }\end{array}$ \\
\hline
\end{tabular}


not the community, to release funds for the disaster recovery projects (Dene, Personal Communication, 2018). Final decision-making of the community takes when electing new council members and mayor. As noted in Figure 2, empower enables final decision-making in the community. Regional Australian Institute (2013) indicates the empowered community shares responsibility in decision making and accountability. Legislative and policy frameworks within the state/country establish the level of power communities might have: some were limited and some wide ranging within a defined time period. In the case of collaboration, there is delegated decision-making, but the government retains the overall decision-making power for the release of funds. The different types of participation are effective in different contexts; empowerment may not be suitable for all situations. Slotterback (2013) noted that effective management of power differences between stakeholders and community can help the community trust the process; some powerful stakeholders might be reluctant in the process if they feel their power is diminished.

\section{RESEARCH METHODS}

To analyze how community empowerment can work in disaster recovery projects, a qualitative case study approach was used to explore the dynamics of empowering the community for long-term sustainability. Case studies are the "the preferred strategy when 'how' or 'why' questions are being posed, when the investigator has little control over events, and when the focus is on a contemporary phenomenon within some real-life context', (Yin, 2012). Case studies can be exploratory, explanatory or descriptive (Yin, 1994).

Within the context of this study, case study research strategy has been selected due to number of reasons. The focus of this study is on natural disasters, specifically geophysical. The most geophysical devastating disaster has been the earthquakes (Guha-Sapir, 2015) in terms of lives and costs. Earthquakes are sudden and devastating events to the community and its environment. A number of aftershocks will take place. It takes many years to rebuild. Two disaster recovery case studies were selected for comparative analysis to understand how Project Managers can empower the community. The case studies were selected in San Francisco and Christ Church through assessment process on accessibility of interviewers. Within these two geographical regions, Project Managers and Community Leaders were interviewed to compare each other's views and experience of community empowerment during disaster recovery. Multiple case studies were used to strengthen the aim and objectives of this study by comparing two earthquake sites and comparing Project Manager and Community Leaders perspectives with each site. The multiple case and embedded approach ensured a comprehensive approach to validate each participant's perspective.

The study followed the ethics requirements for post-graduate studies. The following forms were used to meet the ethics requirements:

- Ethics Application Form 
- Invitation letter sample

- Research Participant Consent Form example

- Research Project Information Form

- Risk Assessment forms Research Projects.

A set of questions were formulated for Project Managers and Community Leaders. The set of questions created the basis of semi-structured interviews. The questions focused on HOW community response to disasters, community strategies, community empowerment, how Project Managers work with the community and key factors for empowerment. Semi-structured interviews were used as the data collection method within the study. Nineteenth invitations where sent out by Deputy Program Manager, Neighborhood Empowerment Network, San Francisco in researcher's behalf. Fourteen individuals (Project Managers and Community Leaders) responded to be interviewed over SKYPE, Google Hangout and Phone. In the case of Christ Church, 30 invitations were sent via contacts, cold calls, and referrals in Wellington and Christ Church, New Zealand. Only 11 individuals were interviewed over SKPE, Google Hangout and Phone. The list of interviewees is shown in Table 1. The researcher contacted fourteenth of their global contacts with expertise in emergency management, disaster management, project management and community development to validate the research findings in June 2018 as shown in Table 2.

Interviews were recorded and transcribed. Researcher used content analysis for data analysis and NVivo was used to help content analysis.

Table 1. List of interviewees

\begin{tabular}{|l|l|l|l|}
\hline \multicolumn{1}{|c|}{ San Francisco Interviewees } & \multicolumn{1}{c|}{ Christchurch Interviewees } \\
\hline Group & \multicolumn{1}{|c|}{ Group } & \multicolumn{1}{c|}{ ID } \\
\hline Project Manager & SF_1 & Project Manager & NZ_1 \\
\hline Community Leader & SF_2 & Project Manager & NZ_2 \\
\hline Community Leader & SF_3 & Project Manager & NZ_3 \\
\hline Community Leader & SF_4 & Community Leader & NZ_4 \\
\hline Community Leader & SF_5 & Project Manager & NZ_5 \\
\hline Community Leader & SF_6 & Community Leader & NZ_6 \\
\hline Project Manager & SF_7 & Project Manager & NZ_7 \\
\hline Community Leader & SF_8 & Community Leader & NZ_8 \\
\hline Project Manager & SF_9 & Project Manager & NZ_9 \\
\hline Community Leader & SF_10 & Community Leader & NZ_10 \\
\hline Project Manager & SF_11 & Project Manager & NZ_11 \\
\hline Community Leader & SF_12 & & \\
\hline Community Leader & SF_13 & & \\
\hline
\end{tabular}


Table 2. Validation study reviewers

\begin{tabular}{|l|l|l|}
\hline \multicolumn{1}{|c|}{ Categories } & \multicolumn{1}{c|}{ Code } & \multicolumn{1}{c|}{ Pandidate } \\
\hline Community & V_C1 & Part of Study \\
\hline Community & V_C2 & Part of Study \\
\hline Community & V_C3 & External \\
\hline Project Management & V_P1 & External \\
\hline Project Management & V_P2 & External \\
\hline Project Management & V_P3 & External \\
\hline Project Management & V_P4 & Part of Study \\
\hline Project Management & V_P5 & External \\
\hline Project Management & V_P6 & External \\
\hline Disaster Management & V_D1 & External \\
\hline Disaster Management & V_D2 & External \\
\hline Disaster Management & V_D3 & External \\
\hline Disaster Management & V_D4 & External \\
\hline Disaster Management & V_D5 & \\
\hline
\end{tabular}

\section{FINDINGS}

From the content analysis of San Francisco's and Christchurch's interviewees notes the following key factors of empowerment were derived as shown in Table 3:

The key factors for empowerment are the foundation for decision-making of one's own fate during disaster recovery. The key factors within San Francisco are social capital (neighborliness, connectivity within the community for assistance, helping and getting work done). The survivor's mode of the community must be based on SMART principles. SMART is an acronym for goal setting. The acronym stands for Specific, Measurable, Achievable, Relevant and Time bound. Make do, repurpose, and use things smartly to achieve the goals by "thinking out of the box" or viewing the resolution from a different angle. A challenge of implementation is the perception of ownership versus realistic decision making. Within the San Francisco area, the local government has developed programs in community leadership and project management for community leaders and community leaders to work SMART and be

\section{Table 3. Comparison of node theme}

\begin{tabular}{|l|l|l|}
\hline \multicolumn{1}{|c|}{ Themes } & \multicolumn{1}{|c|}{ San Francisco Case Study } & \multicolumn{1}{c|}{ Christ Church Case Study } \\
\hline Key Factors for & Survival Mindset & Social Capital \\
Empowerment & Think SMART & Neighborly help \\
& Coping (Cultural and Social) & Final Decision Making \\
& Cocial Capital & Community Well Being \\
& Capacity Building & \\
& Perception of Community Power & \\
\hline
\end{tabular}


survivors through stressors, such as, house fires and work shortages, rather than major disasters, such as earthquakes. Having the community work together in stressors will enable the community to adjust on a daily basis. Interviewee SF_3 outlines the next steps of the empowered community members by "what assets you have, outreach and advocate for constituents, know politicians, form relationships and strategic alignment." These components are key factors to an empowered community that dictates its future direction for sustainment.

The key factors for empowerment of the community within Christ Church were community well-being, participation in the decision-making before final approval by City Council to proceed, neighborly help between community members, and social capital of connections and resources in which the community can organize themselves for a sustainable community. A collective model shapes the framework of empowerment within Christ Church. The model is based on the community leaders being involved in the decision-making prior to City Council approval to proceed with the project. City Council is made of representatives (community leaders) elected by community members. These representatives will change depending on the will of the people.

Information in Table 3 were combined and validated by external reviewers, as shown in Table 2, to form Table 4, the key factors for empowerment.

Each of the tags will be discussed using the interviewees' quotes:

\section{Be and act as a Survivor}

Empowerment means making decisions upon your fate. Within disaster recovery, the community members act as "survivors". The concept of survivor is explained by Interviewee SF_12 recalling Nella's Last Diaries of how mothers survive the bombing and kept on living in WWII in England. Their courage is representative of other people recovering from various disasters in the world: "The people within the community were angry and depressed but kept going on."

Table 4. Themes and tags of community empowerment

\begin{tabular}{|c|c|}
\hline Themes & Tags \\
\hline Key Factors for Empowerment & $\begin{array}{l}\text { - Be and act as a Survivor } \\
\text { - Think and do SMART } \\
\text { - Use Social Capital within the Community } \\
\text { - Build Capacity to take action } \\
\text { - Recognize community power } \\
\text { - Help your Neighbors } \\
\text { - Participate in Decision Making }\end{array}$ \\
\hline
\end{tabular}




\section{Think and do SMART}

Interviewee SF_1 used the Hiker analogy to explain how community members can effectively respond and work after a disaster: "Make do (repurpose and use things smartly) such as a hole in can serve many purposes. Educate the smart things to repurpose items: other ways to achieve the goals. Resources are smartly effectively used". The hiker analogy is applicable for short term needs within the disaster relief and disaster recovery phases. On a longer-term basis for the community members, "finances and economics need to be addressed. Community members who are business owners are motivated to restart their lost business. Restart the lost business helps the other community members within the community to rebuild the community."

The survivor's mode of the community must be based on SMART principles. Make do, repurpose, and use things smartly to achieve the goals by "thinking out of the box" or viewing the resolution from a different angle. Once good information is given then resolution is achieved.

\section{Use Social Capital within the Community}

Interviewee S_9 defined the use of social capital for empowerment as the "talent and resources and professional skills that are inherent in the neighborhood." The skills manifested by the community members will harness the community as an empowered community; community shapes the direction of the rebuilding the community. Connecting these skills as whole, at the community level, is accomplished through associations, such as block parties, or neighborhood parties. SF_13 describes how this formation takes place: "More I know my neighbors who are the survivors to assist the people in my immediate area. Build relationships in my block. We would gather in a local place. This group of people who they know in the block to know most vulnerable, medical. Once assess, the group will go to the next block. Assess the next block. That will link to gather information to need extreme assistance and how to gather information." The community becomes acknowledge by their numbers and support for one another to shape the community future direction after disasters with accurate and reliable information. These principles are currently practiced by various San Francisco communities handling stressors (fires, drought, and power outages).

\section{Build Capacity to take action}

Those communities with high capacity prior to disaster can recover quicker than those without. Different communities have different expectations. Those that may be more entitled shout for more; whereas those that were already disadvantaged do not always consider themselves "worthy" or entitled. It is important to look at home ownership, income, and education with regards to community capacity. The capacity of the community is shaped by its social capital. Social capital provides financial (e.g., loans and gifts for property repair) and nonfinancial resources (e.g., search and 
rescue, debris removal, child care during recovery, emotional support, sheltering, and information).

\section{Recognize community power}

Prior experience with the government indicates the community has limiting power. Limiting power is based upon the funds accessible by the community through direct funds or funds matching. The funders, such as the government and International Banks, have final say. As shown with FEMA future directions, the first 72 hours the community is on its own; the community must take care of itself. The original philosophy that government takes care of its people is limited by available money and resources through taxes. The Christchurch government has asked the community to supplant funds through community fund-raising. The community fund-raising addresses specific community needs that government funds were not sufficient, such as community playgrounds. Community fund-raising has resulted in community power being acknowledge in disaster recovery.

To make community empowerment successful, through power, in the disaster recovery project, community representation is essential. Interviewee SF_9 indicates that "Not everyone can sit at the planning table." Not all community members need or can be involved in the decision-making, but through their natural leaders who are recognized looking after the community, they will have a voice. The community leaders represent the community, hence the community is involved in decision-making.

Christ Church emphasis is an overall community collective engagement model formed on the basis partnership between the community, government and project managers. Emphasis is on government formal recognition of community engagement in all projects. Providing training in governance, community leadership, and project management to enable community leaders on community advisory boards and project control boards to understand and effectively deliver sound products and services for a sustainable community in the long-term. The result is the formation of a Citizen advisory group and involvement in a Project Control Board. Collaboration and consultation are used as the building is being designed. As the building is being constructed, the community is informed of the progress.

For Community empowerment to be present, interviewee NZ_8 states formal recognition and endorsement by "City council and Program/Project managers. City council provides strategic direction; Program/Project Manager carries out the community engagement" needs to take place. With the endorsement of various capital projects, such as the Central Library, Town Hall, community centers and Memorial Center was able to build with community input and endorsement as members are active decision-makers before City Council gave their approval. The endorsement set by City Council setup a framework for partnership through the Community Empowerment Model. There has been examples that Project Manager had previous community empowerment experience which help the Memorial project be very successful. 


\section{Help your neighbours}

Another factor for empowerment, described by interviewee NZ_4, is help your neighbours: "You live in the street for many years. All kids grew up together. Help one another. It was called neighborly. Hard to work now because they are mobile; only identified by religion or sport or cultural. People help one another without being reimbursed." The Christ Church people came from different countries and associated with people along common grounds of young families and children. As young children play in the neighborhood and attend elementary school, the children network and adult network build and grow. Religious facilities further developed helping one another. Neighbourly help becomes a key factor for empowerment.

\section{Participate in Decision Making}

Interviewee SF_9 summarizes community empowerment as: "Community ideas and wisdom helps to shape the community. Empower to be shape decision making. Would they go that far? That is part of empowerment." Interviewee SF_8 further explains empowerment based upon the community is knowledgeable of its nuances which has a great benefit to the disaster recovery project:

- "to understand what the culture wants,

- to assess (talk to people, gather people together, a lot of discussion),

- how to engage the people,

- help people facilitate for decision making, and

- How to establish priority which affects them".

According to NZ_9 "Community feedback is valuable to the project. No technical advice given. Dealt with how the street or community center would look like". This comment is reflective of the other interviewee (NZ_5and NZ_8) that council makes the final decision, not the community. "Community provides input in how the programs, such as swimming and tennis, are delivered. Take the feedback back to council for approval." Council is the legal body to approve the contracts to proceed but the community is empowered in the decision-making before Council makes its decision. Interviewee NZ_9 summarizes the role of decision-making for community empowerment: "People has to be center of everything who were impacted by the earthquake. How to get people to work with people to work with agencies and government: bottom-up approach and partnership".

The key factors for empowerment indicated by the interviewees and reviewers are: be and act as a Survivor; think and do SMART; use Social Capital within the community; build capacity to take action; recognize community power; help your neighbors; and participate in decision making 


\section{DISCUSSION}

Reviewers and interviewees recommended that community empowerment be an ongoing activity present in all phases of Disaster Management (mitigation, preparedness, response, recovery and reconstruction). Disaster plans are created in preparation for disaster to recover quickly and minimize damages. Financiers need to supply sufficient funds through bonds and long-term financing for recovery. Setting up these financial resources takes time, especially when obtaining international loans, which needs time to be repaid. There is a lot of research on mitigation and preparedness in relationship to community empowerment. Focus of the study was on recovery and reconstruction to examine if community empowerment can occur after a disaster.

The key factors of empowerment from the study are strengthened by cultural impact shown through Bosman and Denters' work (2013). Their work indicated the Dutch people mindset was to build "a better place" rather than going to "a better place". Going to "a better place" means transferring the community to another location, which global literature recommends should not happen but often happens in the United States. The Dutch re-built a demolished community by building "a better place" for its community members. The community members participate in designing their new homes. This was encouraged by the lead architect and government. Community empowerment was made to happen. The same situation arose in Christ Church and San Francisco. Interviewees stressed survival mindset, thinking SMART, social capital, capacity building, neighborly help, and a collective model of working together.

San Francisco is noted for its work on empowered communities. Within the San Francisco area, the San Francisco government has developed an Empowered Communities Program's Neighborhood HUB Initiative to harness social capital for neighborhoods to take care of themselves. This initiative supports neighborhoods to create a local network of organizations for overall preparedness on a daily basis, as well as provides essential support to residents as they recover from a stressful event, such as, fire, blackout, tremor or earthquake. Projects are created by the community to rebuild part of the neighborhood. The community members are trained in project management and leadership to create and implement the projects. The Empowered Community Program (ECP) offers communities a bottom-up planning and implementation process that puts community leadership in charge of creating their resiliency strategy from the very beginning; as a result, it increases the likelihood of sustained participation by key local stakeholders at the neighborhood level. The capacity of neighborhoodlevel leadership is to create and nurture local networks in trust and reciprocity. The network will serve the needs of vulnerable residents before, during, and after times of stress. The network extends from the individual to neighbors to family or community organizations to civic organizations.

In the case of Christchurch, community engagement activities (inform to empower) took some time but was achieved through trials and errors by the Christchurch government and the community. Initially, the community was asked for feedback on how the new Christchurch should look like. The feedback initiative 
was internationally recognized. Eventually the community leaders were invited unto Project Control Board and Citizen Advisory Committees of Capital Projects for their input and decisions as contracts were created and implemented. The leaders received project management training. There is some progress of having community members implement the capital project in specific areas, such as gardening, landscaping and painting. The Regenerate Christchurch was implemented last year which encouraged community leaders and members to be formally recognized in the decision-making process. Recently, Christchurch government is encouraging community-led projects by the community. Community runs the project from concept to implementation to maintenance. There have been some local organizations helping community members run their own projects. Christchurch is not at the same stage as San Francisco of incorporating all phases of disaster management at the community level. Given some time and Christchurch will receive the same state and may surpass.

Project Managers and Community Leaders were selected to be interviewed from San Francisco and Christchurch for this study on community empowerment. Their insights and lessons learned were valuable to derive the key factors of empowerment than can be used in other cities and countries facing disaster recovery. The study identified key factors of community empowerment for Project Managers to work with during disaster recovery leading to long-term sustainability of the community.

\section{CONCLUSION}

In conclusion, the factors for community empowerment obtained through research for community members are:

- Active to rebuild their lives as survivors.

- Achieve their recovery goals as SMART (Specific, Measurable, Achievable, Relevant and Time bound) business goals.

- Use Social Capital through their networks to recover their lives.

- Recognize the community as having power for decision-making, raising funds and taking action for recovery by government and disaster recovery professionals.

- Help their neighbors and each other.

- Participate in decision-making on the fate of their community during and after disaster recovery.

- To be talked to by government and disaster recovery professionals.

Successful disaster recovery and community stability require a process that achieves acceptance and a sense of involvement from the stakeholders (Crawford et al., 2013). The success of a recovery project should also be measured in terms of that acceptance; a program that is not perceived as legitimate has not succeeded in achieving community acceptance. Victoria State, Australia (2013) indicates that the empowered community must share responsibility in decision making and accountability. Legislative and policy frameworks within the state/country establish the level of power 
communities can decide: some were limited and some wide ranging within a defined time period. In the case of collaboration, there is delegated decision-making, but the government retains the overall decision-making power. The different types of participation is effective in different contexts; empower may not be suitable for all situations. Slotterback (2013) noted that effective management of power differences between stakeholders and community can help the community trust the process; some powerful stakeholders might be reluctant in the process if they feel their power is diminished. The literature review based on lessons learned shows the importance of empowerment through the workings of the Project Manager - Canterbury Earthquake Recovery Authority's literature.

Christ Church and San Francisco emphasis is an overall community collective engagement model that is formed on the basis of partnership between the community, government and project managers. Emphasis is on government formal recognition of community engagement in all disaster recovery projects. Providing training in governance, community leadership and project management to enable community leaders on community advisory boards and project control boards to understand and effectively deliver sound products and services for a sustainable community on the long-term. The result is a community deciding its destiny.

The derived key factors of empowerment forms the baseline for implementation in different cities and countries wishing to use community empowerment within their disaster recovery projects. The baseline is based upon input from interviewers, reviewers and literature review. The next step is to assess the new setting against the baseline to develop plans for implementation. Variation will be found due to sociocultural context and how government operates within the setting. Adjustments will be made to the implementation plans and baseline if necessary. In time, the baseline will be flexible for many different disaster recovery settings.

The countries that have made the most progress in strengthening their capacity to face disasters are those that have built a solid social base, sustained by the "principles of self-care and mutual aid". Only from this base, is the formal disaster management system articulated to continue with the task. Building, maintaining and developing this social base is an arduous and long-term process, which has its origin in a cultural substratum maintained from experience and memory of past disasters. Each disaster is an experience and a learning that prepares the community for the next disaster (and so on). This innate ability must be trained and strengthened like a muscle. It is necessary to install permanent Training programs to teach people to recognize, coexist and respond to the risk in case it becomes a disaster. Through the use of Project Management as a life skill, the empowered community can achieve a sustainable community for the long-term. 


\section{REFERENCES}

Ainuddin, S., \& Routray, J. K. (2012). Institutional framework, key stakeholders and community preparedness for earthquake induced disaster management in Balochistan. Disaster Prevention and Management, 21(1), 22-36. doi:10.1108/09653561211202683

Aldrich, D. (2008). The Crucial Role Civil Society in Disaster Recovery and Japan's Preparedness for Emergencies. Japan Aktuell, 3, 81-96.

Aldrich, D. (2011). The Externalities of Strong Social Capital: Post-Tsunami Recovery in Southeast India. Journal of Civil Society, 7(1), 81-99. doi:10.1080/17448689.20 11.553441

Aldrich, D. (2018). NEN Empowered Communities Program [YouTube video]. Retrieved from https://www.youtube.com/playlist?list=PL_cT4wZmgBBWnsZyV06 1g4hPY1ickARtv\&disable_polymer=true

Amstein. (1969). A Ladder of Citizen Participation. Journal of the American Institute of Planners, 35, 216.

Anderson, W. (2008). Mobilization of the black community following Hurricane Katrina: From disaster assistance to advocacy of social change and equity. International Journal of Mass Emergencies and Disasters, 26(3), 197-217.

Araki, C. (2013). Earthquake and disaster response in the Japanese community: A strengths and community perspective. Journal of Social Work in Disability \& Rehabilitation, 12(1-2), 39-47. doi:10.1080/1536710X.2013.784174 PMID:23679803

Barnshaw, J. (2006). Beyond Disaster: Locating Katrina within an Inequality Context. In Learning from Catastrophe: Quick Response Research in the Wake of Hurricane Katrina (pp. 47-70). Boulder, CO: University of Colorado Natural Hazards Research Applications and Information Center.

Bolin, R. (2006). Race, Class, Ethnicity, and Disaster Vulnerability. In H. Rodríguez, E. Quarantelli, \& R. R. Dynes (Eds.), Handbook of Disaster Research (pp. 113-129). New York: Springer.

Bornstein, L., Lizarralde, G., Gould, K., \& Davidson, C. (2013). Framing responses to post-earthquake Haiti How representations of disasters, reconstruction and human settlements shape resilience. International Journal of Disaster Resilience in the Built Environment, 4(1), 43-57. doi:10.1108/17595901311298991

Bosman, F., Bakker, H., \& Fullilove, M. (2013). Mental Health Center in Post-Disaster Recovery Ten-Year Retrospective of Mediant's Work in Enschede, Netherlands. International Journal of Mental Health, 42(2-3), 130-148. doi:10.2753/IMH00207411420208

Brennan, M. A., Flint, C., \& Barnett, R. (2005). Community Volunteers: The Front Line of Disaster Response. The Journal of Volunteer Administration, 23(4), 52-56.

Canterbury Earthquake Recovery Authority (CERA). (2016), Walking the Recovery Tightrope: EQ Recovery Learning, New Zealand. 
Chandrasekhar, D. (2012). Digging deeper: Participation and non-participation in post-disaster community recovery. Community Development (Columbus, Ohio), 43(5), 614-629. doi:10.1080/15575330.2012.730538

Choguill, M. B. G. (1996). A ladder of community participation for underdeveloped countries. Habitat International, 20(3), 431-444. doi:10.1016/0197-3975(96)00020-3

Crawford, L. H., Taylor, N., \& Blythman, T. (2013). Understanding the permanent / temporary interface: the case of disastrous events. In Proceedings of the IRNOP XI Conference, Oslo, Norway, BI Norwegian Business School, June 16-19.

Crawford, L., Langston, C., \& Bajracharya, B. (2013). Participatory project management for improved disaster resilience. International Journal of Disaster Resilience in the Built Environment, 4(3), 317-333. doi:10.1108/IJDRBE-07-2012-0020

Cretney, R. M. (2016). Local responses to disaster the value of community led post disaster response action in a resilience framework. Disaster Prevention and Management, 25(1), 27-40. doi:10.1108/DPM-02-2015-0043

Davidson, C. H., Johnson, C., Lizarralde, G., Dikmen, N., \& Sliwinski, A. (2006). Truths and myths about community participation in post-disaster housing projects. Habitat International, 31(1), 100-115. doi:10.1016/j.habitatint.2006.08.003

Dynes, R. (2005), Community social capital as the primary basis of resilience. University of Delaware, Disaster Research Center.

Dynes, R. (2006). Social capital: Dealing with community emergencies. Homeland Security Affairs, 2(2), 1-26.

Drury, J. (2012). Collective resilience in mass emergencies and disasters: A social identity model. In J. Jetten, C. Haslam, \& S.A. Haslam (Eds.), The social cure: identity, health and well-being (pp. 195-215). New York: Psychology Press.

Federal Emergency Management Agency (FEMA). (2011). A Whole Community Approach to Emergency Management: Principles, Themes, and Pathways for Action, FDOC 104-008-1. Washington, D.C.: Department of Homeland Security.

United States International Association of Public Participation. (2007). Retrieved from http://www.iap2.org/

Jing, F. (2012). Public Participation in Post-disaster Reconstruction. In Proceedings of the 48th ISOCARP Congress 2012, Public Participation in Post-disaster Reconstruction Plan of New Beichuan Town. Academic Press.

Maginn, P. (2007). Towards more effective community participation in urban regeneration: The potential of collaborative planning and applied ethnography. Qualitative Research, 7(1), 25-43. doi:10.1177/1468794106068020

Olofsson, A. (2007). The preparedness of local authorities for crisis communication with people who have foreign backgrounds - the case of Sweden. International Journal of Mass Emergencies and Disasters, 25(2), 145-173. 
Olshansky, R. B. (2006). Planning after Hurricane Katrina. Journal of the American Planning Association, 72(2), 147-153. doi:10.1080/01944360608976735

Rowlands, A. (2013). Disaster Recovery Management in Australia and the Contribution of Social Work. Journal of Social Work in Disability \& Rehabilitation, 12(1-2), 19-38. doi:10.1080/1536710X.2013.784173 PMID:23679802

Francisco, S. (2016). Empowered Communities Program, Toolkit. California, United States: San Francisco Government.

Slotterback, C., \& Crosby, B. (2012). Designing Public Participation Processes. Public Administration Review, 73(1), 23-34.

Thornley, L., Ball, J., Signal, L., Aho, K., \& Rawson, E. (2013). Building Community Resilience: Learning from the Canterbury earthquakes. Kotuitui, 10(1), 23-35. doi:1 0.1080/1177083X.2014.934846

Twigg, J. (2009), Characteristics of a Disaster-resilient Community: A Guidance Note. London: DFID. Retrieved from http://discovery.ucl.ac.uk/1346086/1/1346086.pdf

UNDP Strategy on Civil Society and Civic Engagement. (2012).

Victoria, A., \& the Department of Environment and Primary Industries. (2013). Types of Engagement. Retrieved from http://www.dse.vic.gov.au/effective-engagement/ developing-an-engagement-plan/types-of-engagement

Vallance, S. (2012). Early Disaster Recovery: A Guide for Communities. Australasian Journal of Disaster and Trauma Studies.

World Bank. (2005b). Learning Lessons from Disaster Recovery: The Case of Mozambique. World Bank. Retrieved from http://www.proventionconsortium.org/?p ageid $=37 \&$ publicationid $=40 \# 40$

World Bank. (2008). Building Resilient Communities: Risk Management and Responses to Natural Disasters.

Yin, R. (1994). Case Study Research: Design \& Methods (2nd ed.). Thousand Oaks, CA: Sage Publications.

Yin, R. K. (2012). Applications of Case Study Research. Sage Publications. 
Tony Van Krieken, MA, PMP, is a project manager and part-time university instructor in the area of information technology and project management. Tony did his final PhD defense in September 2018 on Project Management and Community Engagement after Natural Disasters from Salford University, Center of Disaster Resilience, School of Built Environment, Manchester, United Kingdom. In addition, Tony was the Community Manager for the International Development Community of Practice, Project Management Institute in 2012. The objective of the Community of Practice is to build the capacity of project managers to ensure they can contribute effectively to the implementation of programs aimed at generating a positive cycle of improvement in emerging countries and raise the standard of living.

Chaminda Pathirage works as the Professor of Brownfield Research and Innovation at School of Architecture and Built Environment, University of Wolverhampton. He He was an Investigator for Major Investigator for a Major EU Horizon 2020 funded project titled 'A panEuropean framework for strengthening Critical Infrastructure resilience to climate change- EU-CIRCLE' and also the Co-Investigator for $£ 1.2 M n$ EPSRC funded project titled "A Collaborative Multiagency Platform for Building Resilient Communities' MOBILISE'. Chaminda has held a number of management responsibilities and leadership roles at different levels in higher education such as the Director of the flagship research group, the Centre for Disaster Resilience (CDR) at University of Salford, Director of Postgraduate Research studies for over 200 PhD students and Director of MSc Project Management in Construction programme. He has been successful in securing research grants worth nearly £2 million, publishing more than 100 refereed articles, graduating $15 \mathrm{PhD}$ students, guest editing 3 special journal issues, serving as the chair of an international research conference, delivering a number of keynote speeches and being a member of 3 journal editorial boards. Chaminda has put his efforts into accomplishing an academic career in higher education whilst making original and significant contributions to knowledge, practice and impact on communities, industry, professionals and the wider society. 